University of Nebraska - Lincoln

DigitalCommons@University of Nebraska - Lincoln

$5-28-2005$

Recombinant bovine interleukin-12 stimulates a gut immune response but does not provide resistance to Cryptosporidium parvum infection in neonatal calves

Paolo Pasquali

Ronald Fayer

Dante Zarlenga

Ana Canals

Tine de Marez

See next page for additional authors

Follow this and additional works at: https://digitalcommons.unl.edu/usdaarsfacpub

This Article is brought to you for free and open access by the U.S. Department of Agriculture: Agricultural Research Service, Lincoln, Nebraska at DigitalCommons@University of Nebraska - Lincoln. It has been accepted for inclusion in Publications from USDA-ARS / UNL Faculty by an authorized administrator of DigitalCommons@University of Nebraska - Lincoln. 


\section{Authors}

Paolo Pasquali, Ronald Fayer, Dante Zarlenga, Ana Canals, Tine de Marez, Maria Teresa Gomez Munoz, Sonia Almeria, and Louis C. Gasbarre 


\title{
Recombinant bovine interleukin-12 stimulates a gut immune response but does not provide resistance to Cryptosporidium parvum infection in neonatal calves
}

\author{
Paolo Pasquali ${ }^{\mathrm{a}, \mathrm{b}}$, Ronald Fayer ${ }^{\mathrm{c}}$, Dante Zarlenga ${ }^{\mathrm{b}}$, Ana Canals ${ }^{\mathrm{b}, \mathrm{d}}$, \\ Tine de Marez ${ }^{\mathrm{b}}$, Maria Teresa Gomez Munoz ${ }^{\mathrm{b}, \mathrm{e}}$, \\ Sonia Almeria ${ }^{\mathrm{b}, \mathrm{f}}$, Louis C. Gasbarre ${ }^{\mathrm{b}, *}$ \\ a Istituto Superiore di Sanita', Department of Food Safety and Veterinary Public Health, Rome, Italy \\ ${ }^{\mathrm{b}}$ Bovine and Functional Genomics Laboratory, Animal and Natural Resources Institute, \\ Agricultural Research Service, USDA, Beltsville, MD 20705, USA \\ ${ }^{\mathrm{c}}$ Environmental Microbial Safety Laboratory, Animal and Natural Resources Institute, \\ Agricultural Research Service, USDA, Beltsville, MD 20705, USA \\ ${ }^{\mathrm{d}}$ Ministerio de Administraciones Publicas, Madrid, Spain \\ ${ }^{\mathrm{e}}$ Departamento de Atencion Sanitaria, Salud Publica y Sanidad Animal, Facultad de Ciencias Experimentales y de la Salud, \\ Universidad Cardenal Herrera-CEU, Valencia, Spain \\ ${ }^{\mathrm{f}}$ Parasitology, Veterinary School, Autonomous University of Barcellona, Bellaterra, Spain
}

Received 1 October 2004; received in revised form 20 May 2005; accepted 28 May 2005

\begin{abstract}
This study was undertaken to determine if administration of recombinant bovine interleukin-12 (rBoIL-12) could stimulate a cellular immune response that protected calves from an oral challenge inoculation with Cryptosporidium parvum oocysts. In a first experiment, rBoIL-12 intraperitoneally administered as a single dose 1 day before challenge inoculation, did not alter the course of infection. The percentage of immune competent cells and levels of cytokine gene expression in the ileo-cecal mucosa and in the draining lymph nodes of treated calves were similar to those of untreated control calves. However, when rBoIL-12 was subcutaneously administered daily from 2 days before infection to 2 days after infection, a consistent increase of $\mathrm{T}$ lymphocytes and an higher expression of interferon- $\gamma$ (IFN- $\gamma$ ) was detected. Again, treatment did not alter the course of infection. Similar results were obtained when rBoIL-12 was administered daily for 4 days beginning 2 days after oral inoculation. These data indicate that although rBoIL-12 stimulated a strong immune response in the gut of neonatal calves, the response was not able to provide protection from challenge inoculation with $C$. parvum oocysts.
\end{abstract}

(C) 2005 Published by Elsevier B.V.

Keywords: Cryptosporidium parvum; Cryptosporidiosis; Cattle; Cellular immune response; Cytokine; Interleukin-12

\footnotetext{
* Corresponding author. Tel.: +1 301504 8509; fax: +1 3015046426.

E-mail address: lgasbarr@anri.barc.usda.gov (L.C. Gasbarre).
} 


\section{Introduction}

Cryptosporidium parvum is a ubiquitous parasitic protozoan of animals and humans. The infection is highly prevalent in young livestock and the disease is usually seen in animals around 2 weeks of age. Clinical signs are characterized by diarrhea accompanied by lethargy, fever, dehydration, and poor conditioning (Fayer et al., 1997). The symptoms, however, can vary greatly in severity and duration from calf to calf (Fayer et al., 1998). In addition to its economic importance in livestock, infected animals can shed a large number of oocysts into the environment and these oocysts present a potential risk for human infection.

Most of our present knowledge of the immune response to $C$. parvum infection has been derived from clinical case reports of human infections and studies using murine models (Riggs, 1997, 2002). From the murine studies, it has been determined that cellmediated immune responses provide greater protection than humoral responses for recovery from infection. Both CD4+ $\mathrm{T}$ cells and interferon- $\gamma$ (IFN- $\gamma$ ) are essential for protection against $C$. parvum infection (Ungar et al., 1991; McDonald et al., 1992; Chen et al., 1993; McDonald and Bancroft, 1994; Rehg, 1996; Culshaw et al., 1997; Theodos et al., 1997).

Interleukin-12 (IL-12) is a potent inducer of IFN- $\gamma$ in a variety of cell types both in vitro (Chan et al., 1991) and in vivo (Gately et al., 1994). The effect of IL-12 has been extensively studied in murine models of infection in response to a broad variety of microorganisms (reviewed in Romani et al., 1997). Its role in resistance to experimental infections is ascribed to its proinflammatory activity and to the induction of Th1-like T cell responses (Trinchieri, 1998). In previous studies, mice treated with IL-12 prior to oral inoculation with C. parvum oocysts exhibited a significant reduction in the severity of infection (Urban et al., 1996). These studies also demonstrated that treatment with IL-12 neutralizing antibodies nullified the beneficial effects of IL-12 administration.

In cattle, a primary infection with $C$. parvum induced an increase in CD4+ and CD8+ T lymphocytes in ileal epithelium, and an increase of CD8+ T lymphocytes in the ileal lamina propria, without changes in the ileo-cecal lymph nodes (Pasquali et al., 1997). These changes were associated with a transcriptional increase in mucosal lymphocyte- induced IFN- $\gamma$ (Canals et al., 1998). Combined, these findings strongly suggest that, as in mice, Th1-like responses develop in cattle in response to $C$. parvum infection. As such, the role of IL-12 in the induction of protective immunity needs to be determined.

The recent availability of the 35 and $40 \mathrm{kDa}$ subunits of recombinant bovine IL-12 (rBoIL-12) (Zarlenga et al., 1995a) provided the opportunity to determine if rBoIL-12 could protect newborn calves from a primary C. parvum infection similar to that observed in mice. Different treatment regimens were employed to define the effects of IL-12 on the immune responses in calves.

\section{Materials and methods}

\subsection{Cytokines}

Human recombinant IL-12 (rHuIL-12) was purchased from R\&D Systems (Minneapolis, MN, USA). A single batch of rBoIL-12 (1540 ng/ml) was produced essentially as described elsewhere and provided by Schering Plough (Solano-Aguilar et al., 2002). A unit of biological activity of rBoIL-12 $(284 \mathrm{pg})$ was defined as the amount of IL-12 required to induce one-half the maximal proliferation of lymphoblasts induced by the addition of rHuIL-12.

\subsection{In vitro studies}

\subsubsection{Cell preparation}

Blood was obtained from healthy 4-8-month-old cattle by jugular venipuncture and collected in vacutainer tubes containing EDTA anticoagulant. Peripheral blood mononuclear cells (PBMC) were separated on Ficoll (Sigma Chemical, St. Louis, MO, USA)/Hypaque (Nycomed Inc., Princeton, NJ, USA) density gradients. Lymphoblasts were generated from PBMC $\left(1 \times 10^{6} \mathrm{ml}^{-1}\right)$ cultured in RPMI-1640 medium (Sigma Chemical), supplemented with $100 \mathrm{U}$ of penicillin per $\mathrm{ml}, 100 \mu \mathrm{g}$ of streptomicin per $\mathrm{ml}$, $50 \mu \mathrm{l}$ of kanamycin per ml, $25 \mathrm{mM}$ Hepes, $10 \mu \mathrm{l}$ of glutamine per $\mathrm{ml}, 5 \times 10^{-5} \mathrm{mM}$ mercaptoethanol, and $10 \%$ heat-inactivated calf serum. Cells were maintained in $162 \mathrm{~cm}^{2}$ cell culture flasks (Costar, Cambridge, MA). PBMC were stimulated for 3 days in the presence of Concanavalin A (Con A) (Sigma Chemical) $(2.5 \mu \mathrm{g} /$ $\mathrm{ml})$. Stimulated PBMC were washed twice with 
calcium-magnesium free Hanks' balanced salt solution (HBSS-CMF) (Sigma Chemical) and lymphoblasts were purified on a Percoll (Pharmacia Biotech, Uppsala, Sweden) discontinuous density gradient $(25,40,50$, and $70 \%)$, and collected from the interface between the 40 and the $50 \%$ fractions.

\subsubsection{Proliferation essays}

PBMC were suspended at a concentration of $4 \times 10^{6}$ cells per $\mathrm{ml}$ in RPMI-1640 and lymphoblasts were suspended at a concentration of $5 \times 10^{5}$ cells per $\mathrm{ml}$. The cells were cultured with rBoIL-12 or rHuIL-12 in 96-well flat-bottomed tissue culture plates. Controls consisted of cells exposed to a supernate from cells transfected with control swine poxvirus in the absence of the IL-12 subunit genes (MBP) at different concentrations in 96-well flat-bottomed tissue culture plates $\left(37 \mathrm{C}, 5 \% \mathrm{CO}_{2}\right)$. Lymphoblasts and PBMC were incubated for 3 or 4 days, respectively. The cells were harvested $6 \mathrm{~h}$ after the addition of $0.5 \mu \mathrm{Ci} /$ well of $\left[{ }^{3} \mathrm{H}\right]$ methylthymidine (Amersham Life Science) using a cell harvester (Cambridge Technology Inc., Watertown, MA, USA). The amount of $[3 \mathrm{H}]$ methylthymidine incorporation was measured by liquid scintillation counting (Beckman, Fullerton, CA, USA). Background proliferation was determined by culturing control cells in the culture media alone. Results are presented as the mean counts per minute (cpm) of three stimulated wells minus the mean background counts from unstimulated cells from three wells.

\subsubsection{IFN- $\gamma$ production in vitro}

Lymphoblasts were suspended at a concentration of $2 \times 10^{6}$ cells per $\mathrm{ml}$ in RPMI-1640 (supplemented as previously described). One millilitre of cell suspension plus $1 \mathrm{ml}$ of RPMI- 1640 containing $156 \mathrm{pg} / \mathrm{ml}$ of rBoIL-12 or MBP were incubated in 24-well flatbottomed tissue culture plates. After 24, 48, and $72 \mathrm{~h}$, culture media were collected and the production of IFN- $\gamma$ was measured using a commercial ELISA kit as described by the manufacturer (Mycobacterium paratuberculosis gamma interferon test kit, IDEXX Laboratories Inc., Westbrook, ME, USA) per manufacturer's instructions.

\subsection{In vivo studies}

\subsubsection{Parasites and infection}

The general experimental design is reported in Table 1. C. parvum oocysts used in each experiment were obtained from 1- to 3-week-old Holstein Freisian calves orally inoculated with the AUCP-1 strain. Twenty newborn Holstein Freisian male calves were used in two separate experiments. Calves were housed indoors in $2 \mathrm{~m} \times 3 \mathrm{~m}$ isolated pens throughout the experiments and fed conventional milk replacer twice daily and water was available ad libitum. In the first experiment, rBoIL-12 or MBP were given by an intraperitoneal injection. Eight calves were orally infected with $1 \times 10^{6} \mathrm{C}$. parvum oocysts at 2 days of age and euthanized between 11 and 13 days of age. Of those, four received intraperitoneal injections $(10 \mathrm{ml}$; $54,225 \mathrm{U} ; 15.4 \mu \mathrm{g}$ ) of rBoIL-12 at 1 day of age, and four calves were given $10 \mathrm{ml}$ of MBP. In the second experiment, rBoIL-12 or the MBP were administered by subcutaneous injection. Twelve calves were orally infected with $0.5 \times 10^{6} \mathrm{C}$. parvum oocysts at 2 days of age and killed between 11 and 13 days of age. Four

Table 1

Experimental design

\begin{tabular}{|c|c|c|c|c|c|}
\hline Group & Treatment & Time of treatment & Infection & Time of infection & $\begin{array}{l}\text { Number of } \\
\text { calves }\end{array}$ \\
\hline \multicolumn{6}{|c|}{ First experiment } \\
\hline 1 & $10 \mathrm{ml}$ of $\mathrm{MBP}^{\mathrm{a}}$ & 1 day of age & $1 \times 10^{6}$ oocysts of $C$. parvum & 2 days of age & 4 \\
\hline 2 & $10 \mathrm{ml}$ of $\mathrm{rBoIL}-12^{\mathrm{a}}$ & 1 day of age & $1 \times 10^{6}$ oocysts of $C$. parvum & 2 days of age & 4 \\
\hline \multicolumn{6}{|c|}{ Second experiment } \\
\hline 1 & $4 \mathrm{ml}$ of $\mathrm{MBP}^{\mathrm{b}}$ & $1-4$ days of age & $0.5 \times 10^{6}$ oocysts of $C$. parvum & 2 days of age & 4 \\
\hline 2 & $4 \mathrm{ml}$ of $\mathrm{rBoIL}-12^{\mathrm{b}}$ & $1-4$ days of age & $0.5 \times 10^{6}$ oocysts of $C$. parvum & 2 days of age & 4 \\
\hline 3 & $4 \mathrm{ml}$ of $\mathrm{rBoIL}-12^{\mathrm{b}}$ & 4-7 days of age & $0.5 \times 10^{6}$ oocysts of $C$. parvum & 2 days of age & 4 \\
\hline
\end{tabular}

\footnotetext{
${ }^{\text {a }}$ Treatment (i.p.).

b Treatment (SC).
} 
calves (group 1) were each administered four doses of $4 \mathrm{ml}$ each of MBP at 1-4 days of age, four calves (group 2) were each administered four doses of $4 \mathrm{ml}$ $(21,690 \mathrm{U}, 6.16 \mu \mathrm{g})$ of rBoIL-12 at 1-4 days of age, and the remaining four calves (group 3) were each given four doses of $4 \mathrm{ml}$ each of rBoIL-12 at 4-7 days of age. Feces were collected daily from the rectum of each calf and the number of oocysts, and the severity of diarrhea was determined as previously described (Fayer et al., 1998). After euthanizing the calves, lymph nodes draining the ileum, discrete mesenteric lymph nodes and an approximately $10 \mathrm{~g}$ segment of ileum just anterior to the continuous ileal Peyer's patch were taken from each calf. Ileo-cecal lymph node (ICLN), intraepithelial (IEL), and lamina propria (LPL) lymphocytes were isolated as previously described (Gasbarre, 1994; Pasquali et al., 1997). Briefly, ICLN were collected by teasing apart the nodes and removing the debris by sedimentation. IEL were collected by three incubations in HBSS-CMF containing $5 \mathrm{mM}$ EDTA on a magnetic stirrer. After each incubation, media were collected and debris was eliminated by sedimentation. LPL were collected after incubation of the remaining tissues three times, with stirring, in HBSS-CMF containing dispase II neutral protease $(1.5 \mathrm{mg} / \mathrm{ml})$. The IEL and LPL were further purified by Percoll discontinuous density gradient centrifugation (40 and 80\%). Phenotypic analysis was performed by indirect immunofluorescence as previously described (Gasbarre, 1994) using monoclonal antibodies against bovine CD3, CD4, CD8, IL-2Ralfa, B-B4, $\gamma \delta$, and CD14 (WMRD, Pullman, WA).

\subsubsection{Competitive RT-PCR for cytokine gene expression}

Lymphocytes were lysed in $3 \mathrm{ml}$ of guanidinium isothiocyanate buffer and total RNA was isolated as previously described (Canals et al., 1998). All samples were DNAse treated (2.5 U DNase, RNase free; 5 min, $37^{\circ} \mathrm{C}$ ) in the presence of $80 \mathrm{U}$ of RNase inhibitor to eliminate contaminating genomic DNA. RNA concentration was determined spectrophotometrically and integrity checked by denaturing agarose gel electrophoresis.

Total RNA $(5 \mu \mathrm{g})$ isolated from the lymphoblasts was used for the synthesis of cDNA in a reaction volume of $20 \mu \mathrm{l}$ in the presence of oligo dT and Superscript II, (Invitrogen, Gaithersburg, MD). PCR amplifications were performed in $25 \mu$, containing $1 \mu \mathrm{l}$ of cDNA, $0.2 \mu \mathrm{M}$ of each primer, $10 \mathrm{mM}$ Tris$\mathrm{HCl}(\mathrm{pH} 8.3), 1.5 \mathrm{mM} \mathrm{MgCl} 2,50 \mathrm{mM} \mathrm{KCl}, 200 \mu \mathrm{M}$ dNTP, $0.8 \mathrm{U}$ of Taq DNA polymerase, and a concentration of plasmid competitor empirically determined for each experiment. Competitor molecules for bovine cytokines were constructed as previously described (Zarlenga et al., 1995b). The size of the amplified products and the primer information are listed in Table 2. The amplification program consisted of 35 cycles at $94{ }^{\circ} \mathrm{C}$ for $1 \mathrm{~min}$, $55^{\circ} \mathrm{C}$ for $1 \mathrm{~min}$, and $72{ }^{\circ} \mathrm{C}$ for $2 \mathrm{~min}$. The PCR products were run on a $1.8 \%$ Metaphor: $0.2 \%$ GTG agarose gel and stained with ethidium bromide. Amplification of hypoxanthine phosphoribosyltransferase (HPRT) from cDNA in the presence of the corresponding competitor molecule was used as a

Table 2

Cytokine competitors, size (bp) of fragment amplified from cDNA and competitor, and forward and reverse primer sequences used in the competitive RT-PCR

\begin{tabular}{lll}
\hline Cytokine competitor & Competitor size & Primer \\
\hline IL-2 & 323 & $\begin{array}{l}\text { GTACAAGATACAACTCTTGTCTTGC (F) } \\
\text { GTCATTGTTGAGTAGATGCTTTGACAAAAGG (R) }\end{array}$ \\
IL-10 & 465 & $\begin{array}{l}\text { ATGCATAGCTCAGCACTACTCTGTTGCCTG (F) } \\
\text { TCACTTTTGCATCTTCGTTGTCATGTAGGTT (R) }\end{array}$ \\
IFN- $\gamma$ & 310 & TATGGCCAGGGCCAATTTTTTAGAGAAATA (F) \\
TNF- $\alpha$ & 320 & TTACGTTGATGCTCTCCGGCCTCGAAAGAG (R) \\
HPRT & \multirow{2}{*}{186} & CAAGAATTCAGGTCCTCTTCTCAAGCCTCAAGTAAC (F) \\
& & TTTGGATCCCGGCAGGTTGATCTCAGCACTGAGG (R) \\
& GGAGATGATCTCTCAACTTTAACTGG (F) \\
\hline
\end{tabular}


control for cDNA synthesis. The cDNAs were adjusted in order to keep HPRT ratios of cDNA to competitor approximately equal to 1 . Intensities of fluorescent bands from scanned gels containing amplified native cDNA were quantified.

\subsection{Statistical analysis}

Statistical significance was evaluated by a one-way analysis of variance (ANOVA). Differences were considered significant when $P \leq 0.05$.

\section{Results}

\subsection{Effect of rBoIL-12 in vitro}

The in vitro biological activity of rBoIL-12 was assessed by its ability to induce a proliferation in PBMC and activated Con A lymphoblasts (Fig. 1). rBoIL-12 induced significant proliferation of lymphoblasts after 3 days in culture where rHuIL-12, applied at the same concentration as rBoIL-12, induced a lower level of stimulation. MBP did not induce any
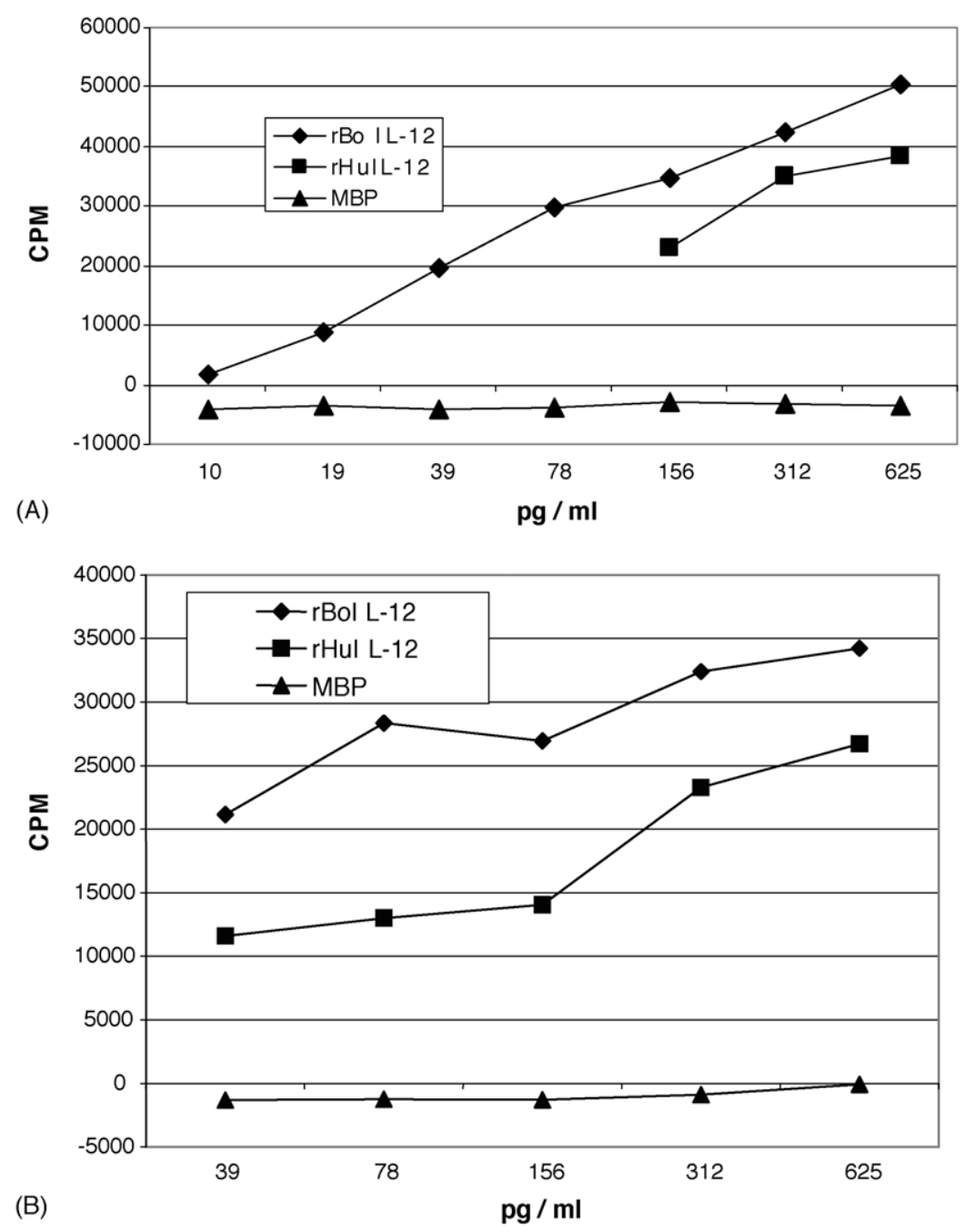

Fig. 1. (A) Proliferative response of bovine lymphoblasts stimulated with different concentration of rHuIL-12, rBoIL-12, or MBP (mean CMP of stimulated wells minus the mean background counts from unstimulated cells) and (B) proliferative response of bovine PBMC stimulated with rHuIL-12, rBoIL-12, or MBP (mean CMP of stimulated wells minus the mean background counts from unstimulated cells). 


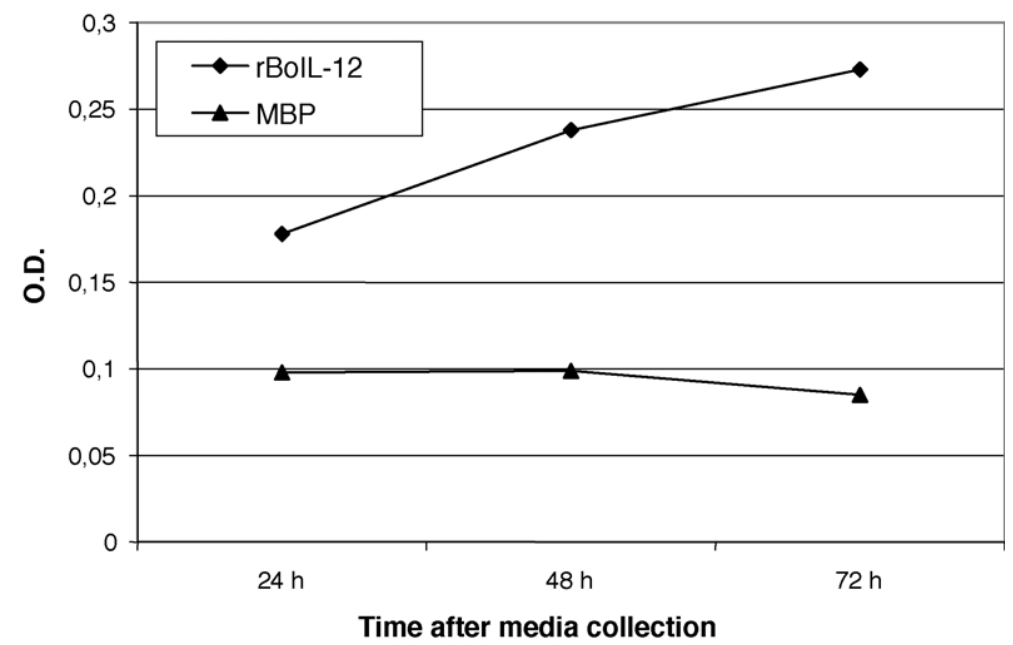

Fig. 2. IFN- $\gamma$ production of lymphoblasts after stimulation with rBoIL-12 (312 pg/ml).

proliferation. Both rBoIL-12 and rHuIL-12 demonstrated a dose-dependent stimulatory effect on PBMC (Fig. 1). The level of activation, however, was lower compared to the stimulation observed for lymphoblasts. MBP did not induce proliferation. IFN- $\gamma$ production by lymphoblasts cultured for 24,48 , and $72 \mathrm{~h}$ with rBoIL-12 or MBP is shown in Fig. 2. rBoIL12 induced a dose-dependent IFN- $\gamma$ production whereas MBP had no effect.

\subsection{Effect of rBoIL-12 in vivo}

All infected calves began oocyst shedding between 3 and 5 days after oral exposure to oocyst inoculum. In the first experiment, treatment with a single dose of rBoIL-12 1 day before oral inoculation with $C$. parvum oocysts did not alter the course of infection or induce measurable immunologic differences, as defined herein. The percentage cell subsets in IEL, LPL, and LNL were not different between calves treated with rBoIL-12 and those treated with MBP (negative controls). The levels of cytokine expression were similar between groups and no differences were seen in terms of diarrhea severity, oocyst shedding intensity, and duration of infection (data not shown).

In the second experiment, administration of rBoIL12 at $1-4$ days of age induced a consistent increase of $\mathrm{CD} 3+, \mathrm{CD} 4+$, and $\mathrm{CD} 8+\mathrm{T}$ cells in all three tissues

Table 3

Percentage of intraepithelial (IEL), lamina propria (LPL), and ileo-cecal lymph node (LNL) leukocytes positive for cell surface markers

\begin{tabular}{|c|c|c|c|c|c|c|c|c|c|}
\hline & \multicolumn{9}{|l|}{ Groups } \\
\hline & \multicolumn{3}{|l|}{ IEL } & \multicolumn{3}{|l|}{ LPL } & \multicolumn{3}{|l|}{ LNL } \\
\hline & 1 & 2 & 3 & 1 & 2 & 3 & 1 & 2 & 3 \\
\hline CD3 & $72.4(5.6) \mathrm{a}$ & $83.4(0.9) \mathrm{a}$ & $82.1(0.9) \mathrm{a}$ & $59.4(2.3) \mathrm{a}$ & $62.5(3.5) \mathrm{a}$ & $74.9(2.4) \mathrm{b}$ & $59.8(4.5) \mathrm{a}$ & 68.9 (3.6)a & $72.9(1.8) \mathrm{b}$ \\
\hline CD4 & $5.9(1.5) \mathrm{a}$ & $11.5(1.7) \mathrm{b}$ & $11.6(3.6) \mathrm{b}$ & $3.4(0.7) \mathrm{a}$ & $6.9(1.7) \mathrm{a}$ & $4.0(0.9) \mathrm{a}$ & $38.1(4.1) \mathrm{a}$ & $43.1(5.0) \mathrm{a}$ & $50.1(2.5) \mathrm{b}$ \\
\hline CD8 & $23.0(2.9) \mathrm{a}$ & $32.4(2.5) \mathrm{b}$ & $27.6(2.0) \mathrm{a}$ & $10.8(1.3) \mathrm{a}$ & $12.4(1.5) \mathrm{a}$ & $16.6(3.2) \mathrm{a}$ & $17.5(2.7) \mathrm{a}$ & $21.4(2.4) \mathrm{a}$ & $21.4(0.9) \mathrm{a}$ \\
\hline IL2R & $22.4(5.6) \mathrm{a}$ & $15.7(1.6) \mathrm{a}$ & $17.7(6.0) \mathrm{a}$ & $14.3(3.0) \mathrm{a}$ & $20.5(4.3) \mathrm{a}$ & $22.6(5.4) \mathrm{a}$ & $15.6(5.2) \mathrm{a}$ & $19.5(5.8) \mathrm{a}$ & $11.8(0.6) \mathrm{a}$ \\
\hline$\gamma \delta$ & $5.8(0.5) \mathrm{a}$ & $6.9(1.3) \mathrm{a}$ & 9.1 (1.9)a & $3.9(0.4) \mathrm{a}$ & $3.0(0.6) \mathrm{a}$ & $8.2(2.4) \mathrm{a}$ & $8.4(0.8) \mathrm{a}$ & 8.7 (1.6)a & $9.7(0.6) \mathrm{a}$ \\
\hline B & $6.0(1.4) \mathrm{a}$ & $4.9(1.0) \mathrm{a}$ & $6.2(1.5) \mathrm{a}$ & $4.3(0.8) \mathrm{a}$ & $4.4(0.8) \mathrm{a}$ & $4.1(0.6) \mathrm{a}$ & $21.9(3.3) \mathrm{a}$ & $17.8(2.8) \mathrm{a}$ & $18.3(2.3) \mathrm{a}$ \\
\hline CD14 & $4.8(1.8) \mathrm{a}$ & $4.7(1.0) \mathrm{a}$ & $5.1(1.7) \mathrm{a}$ & $1.7(0.1) a, b$ & $0.9(0.4) \mathrm{a}$ & $3.9(0.6) \mathrm{b}$ & $10.9(0.6) \mathrm{a}$ & $8.3(1.3) \mathrm{a}$ & $11.9(1.2) \mathrm{a}$ \\
\hline
\end{tabular}

Values expressed are the mean percentage (S.E.) of different treatment groups. Group 1: calves inoculated with binding protein at 1-4 days of age (control group); group 2: calves inoculated with rBoIL-12 at 1-4 days of age; group 3: calves inoculated with rBoIL-12 at 4-7 days of age. Values with no letter in common are significantly different $(P \leq 0.05)$. 


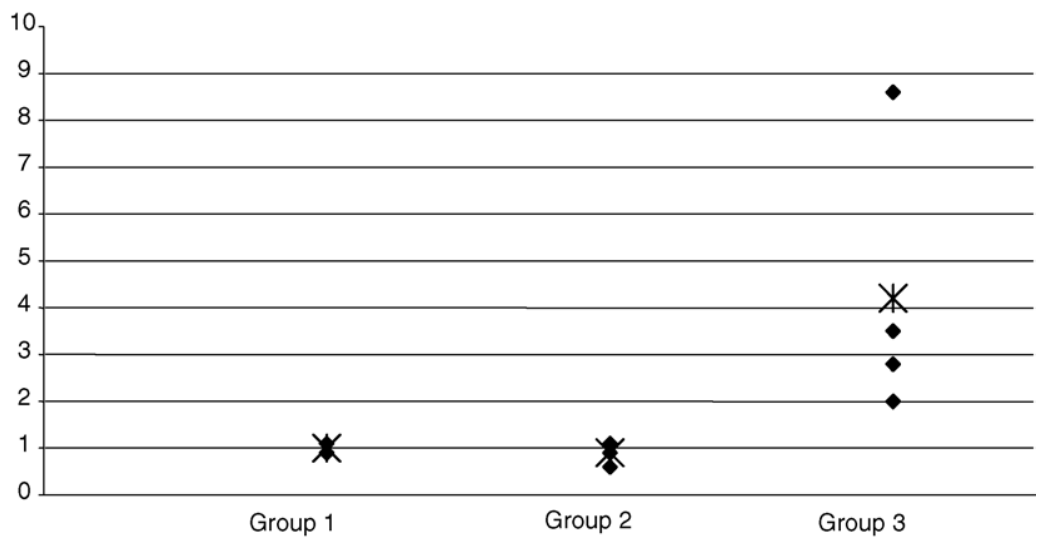

Fig. 3. Cytokine RNA analysis of IFN- $\gamma$ in LNL. Results are expressed as fluorescence intensities ratios of amplified native cDNA to competitor and normalized to the HPRT values. Individual values (diamonds) and group means (asterisks) are indicated.

examined, although to different degrees (Table 3). Statistically significant differences were seen for the percentage of CD4+ and CD8+ T cells in the ileal epithelium of calves treated with rBoIL-12 beginning 1 day before infection (group 2) compared to the percentage of cells from calves treated with MBP (group 1). There was a significant increase in the percentage of $\mathrm{CD} 3+\mathrm{T}$ cells in the lamina propria from calves treated at 4-7 days of age with rBoIL-12 beginning 2 days after infection (group 3) compared to those treated with MBP (group 1) or with rBoIL-12 beginning 1 day before infection (group 2). Finally, there was a significant increase in CD3+ and CD4+ T cells in the ileo-cecal lymph nodes from calves treated with rBoIL-12 beginning 2 days after infection (group 3) compared to those treated with MBP (group 1) or with rBoIL-12 beginning 1 day before infection (group 2).

Using competitive RT-PCR, a cumulative assessment of cytokine gene expression was obtained from
IEL, LPL, and LNL. All three cell populations showed detectable levels of expression for the tested cytokines. In LNL there was a significant increase of expression of IFN- $\gamma$ in calves in calves treated with rBoIL-12 beginning 2 days after infection (group 3) (Fig. 3). IEL and LPL showed substantially higher expression of mRNA for IFN- $\gamma$ and TNF- $\alpha$ in some calves treated with rBoIL-12 beginning 1 day before infection (group 2) although the differences were not statistically significant (data not shown). The other cytokines showed similar level of expression in the tissues examined (data not shown).

The effect of different regimens of rBoIL-12 on the course of the infection in the different groups of calves is shown in Table 4. Except for a slight reduction of oocyst production in calves treated with rBoIL-12 beginning 1 day before infection (group 2), the other parameters were similar in all the tested groups.

Table 4

Prepatent and patent periods of oocyst excretion, oocyst output, and diarrhea in calves treated with rBoIL-12 or MBP and infected with $C$. parvum at 2 days of age

\begin{tabular}{lccc}
\hline & \multicolumn{1}{l}{ Calves } & & \\
\cline { 2 - 4 } & Group 1 & Group 2 & Group 3 \\
\hline First day oocyst excreted & $3.25(0.5)$ & $3.75(0.96)$ & $3.75(0.5)$ \\
Days of diarrhea & $5.25(1.5)$ & $4.75(0.96)$ & $4.00(2.4)$ \\
Oocyst production $\left(\times 10^{6} \mathrm{~g}^{-1}\right.$ of feces) & $0.94(0.39)$ & $0.45(0.1)$ & $1.39(1.3)$ \\
Diarrhea severity index & $13.25(6.3)$ & $10.5(1.9)$ & $10.0(6.3)$ \\
\hline
\end{tabular}

Values expressed are the mean percentage (S.D.). Group 1: calves inoculated with binding protein at 1-4 days of age (control group); group 2: calves inoculated with rBoIL-12 at 1-4 days of age; group 3: calves inoculated with rBoIL-12 at 4-7 days of age. 


\section{Discussion}

This study demonstrates for the first time that rBoIL-12 can stimulate immune response in the neonatal bovine. Our results clearly demonstrate that rBoIL-12 exerted biological activity both in vitro and in vivo. rBoIL-12 induced a dose-dependent proliferative response in resting (PBMC) and activated $\mathrm{T}$ cells (lymphoblasts), and stimulated IFN- $\gamma$ production in lymphoblasts. These data demonstrate that rBoIL12 possesses biological activities similar to that reported in humans and mice. In addition, administration of rBolL-12 to calves increased the percentage of $\mathrm{T}$ cell populations both in the gut and in the draining lymph nodes, and increased IFN- $\gamma$ gene expression in the gut and in the draining lymph nodes of neonatal calves experimentally infected with $C$. parvum. The results reported do not address whether the rBoIL-12 stimulated innate or cognate immune response, but in other animal models (Grohmann et al., 2001), IL-12 was shown to act in both autocrine and paracrine responses.

In this study administration of exogenous rBoIL12 did not modify the course of an experimental C. parvum infection. These results are in contrast to those previously reported which showed that murine IL-12 was able to induce protection in neonatal mice (Urban et al., 1996). The most obvious explanation for this apparent discrepancy may be the fact that while cattle and mice share many common features in the immune response to C. pavum, in cattle IL-12 alone may be an insufficient stimulator of protective immunity to $C$. parvum. Information concerning the role of cytokines in cattle, and in particular that of IL-12, is sparse and fragmented. Reports from experimental studies have described increased IFN$\gamma$ production by peripheral blood mononuclear cells from infected calves stimulated with $C$. parvum antigens (de Graaf and Peeters, 1997), an increase in IFN- $\gamma$ mRNA expression in the mucosa of $C$. parvum infected calves (Canals et al., 1998), and a type-1-like immune response in the gut of calves recovering from cryptosporidiosis (Wyatt et al., 2001). These results imply, that similar to murine models, IFN- $\gamma$ is involved in the immune response to cryptosporidiosis in cattle. However, little information is available regarding the specific effects of IL-12 on immunocompetent cell populations in cattle.
Another reason for the observed lack of protection after administration of rBoIL- 12 could be related to the timing of the experiment, and it is possible that the rBoIL-12 was not given at the right time to prevent or ameliorate the course of the $C$. parvum development. In a previous study, the greatest protection from IL-12 in mice was seen when treatment was given 1 day before infection or the day of the infection to $C$. parvum (Urban et al., 1996). Based on these mouse experiments, calves in the present study were given rBoIL-12 starting 1 day before infection (group 2), or 2 days after infection (group 3), and both groups showed substantial changes in the immune response. In spite of these observed changes, protection may require a different temporal regimen which must be determined by a complex dose and time titration. Such an experiment in cattle is prohibitorily expensive.

It is interesting to note that calves treated with rBoIL-12 beginning 2 days after infection (group 3), which received the last rBoIL-12 treatment 4-6 days before euthanasia, showed major changes in ICLN. These modifications were characterized by an increase in $\mathrm{T}$ cells and IFN- $\gamma$ gene expression. In contrast, calves treated with rBoIL-12 beginning 1 day before infection (group 2), which received the last inoculation of rBoIL-12 7-9 days before euthanasia, showed major changes in the gut, and especially in the lamina propria. These results suggest that in neonatal calves rBoIL-12 requires additional time to modify the immune response, and that the effects of IL-12 are observable initially in the regional lymph nodes followed later in the intestinal mucosa. This would indicate that infection occurred prior to alterations of the intestinal milieu by the rBoIL-12 treatment. Therefore, it would be interesting to determine if oral administration of rBoIL-12 is more effective in stimulating the mucosal immune response, than parenteral administration.

Finally, our results imply that IL-12-driven stimulation of immune responses and IL-12-driven protection against $C$. parvum might require vastly different doses. In the second experiment, where rBoIL-12 was given for 4 days at a dose of $4 \mathrm{ml}$ daily $(6160 \mathrm{ng} /$ day) there was a stimulation of a predictable immune response within neonatal calves but this was insufficient to modify the course of experimental 
infection with $C$. parvum. The dose given to bovines was far from equal, relatively to body weight, to that given to mice, where a dose-dependent effect is achieved a dose ranging from 200 to $1000 \mathrm{ng}$. The cost and difficulty of using a comparable rBoIL-12, make similar experiments impractical and suggest that rBoIL-12 maybe better evaluated as an adjuvant for use in conjunction with antigens to prime a specific immune response rather than use as a sole immunopotentiator.

In conclusion, this report indicates that rBoIL-12 given to neonatal calves can stimulate the immune system, but that at practical doses, such stimulation is not able to modify the course of $C$. parvum infection. This implies additional information is required to better understand the role of IL-12 in the immune system of cattle, and in particular in neonatal calves that are so highly susceptible to a number of infectious agents.

\section{References}

Canals, A., Pasquali, P., Zarlenga, D.S., Fayer, R., Almeria, S., Gasbarre, L.C., 1998. Local ileal cytokine responses in cattle during a primary infection with Cryptosporidium parvum. J. Parasitol. 84, 125-130.

Chan, S.H., Perussia, B., Gupta, J.W., Kobayashi, M., Pospisil, M., Young, H.A., Wolf, S.F., Young, D., Clark, S.C., Trinchieri, G., 1991. Induction of interferon "gamma" production by natural killer cell stimulatory factor: characterization of the responder cells and sinergy with other inducers. J. Exp. Med. 173, 869879.

Chen, W., Harp, J.A., Harmsen, A.G., Havell, E.A., 1993. Gamma interferon functions in resistance to Cryptosporidium parvum infection in severe combined immunodeficient mice. Infect. Immun. 61, 3548-3551.

Culshaw, R.J., Bancroft, G.J., McDonald, V., 1997. Gut intraephitelial lymphocytes induce immunity against Cryptosporidium infection through a mechanism involving gamma interferon production. Infect. Immun. 65, 3074-3079.

de Graaf, D.C., Peeters, J.E., 1997. Specific interferon-gamma, IgA and IgM responses after experimental infection of neonatal calves with Cryptosporidium parvum. Int. J. Parasitol. 27, 131-134.

Fayer, R., Speer, C.A., Dubey, J.P., 1997. The general biology of Cryptosporidium. In: Fayer, R. (Ed.), Cryptosporidium and Cryptosporidiosis. CRC Press, Boca Raton, FL, pp. 1-41.

Fayer, R., Gasbarre, L., Pasquali, P., Canals, A., Almeria, S., Zarlenga, D., 1998. Cryptosporidium parvum infection in bovine neonates: dynamic clinical, parasitic and immunologic patterns. Int. J. Parasitol. 28, 49-56.
Gasbarre, L.C., 1994. Ostertagia ostertagi: changes in lymphoid populations in the local lymphoid tissues after primary and secondary infection. Vet. Parasitol. 55, 105-114.

Gately, M.K., Warrier, R.R., Honasoge, S., Carvajal, D.M., Faherty, D.A., Connaughton, S.E., Anderson, T.D., Sarmiento, U., Hubbard, B.R., Murphy, M., 1994. Administration of recombinant IL-12 to normal mice enhances cytolytic lymphocyte activity and induces production of IFN-gamma in vivo. Int. Immunol. 6, 157-167.

Grohmann, U., Belladonna, M.R., Vacca, C., Bianchi, R., Fallarino, F., Orabona, C., Fioretti, M.C., Puccetti, P., 2001. Positive regulatory role of IL-12 in macrophages and modulation by IFN gamma. J. Immunol. 167, 221-227.

McDonald, V., Deer, R., Uni, S., Iseki, M., Bancroft, G.J., 1992. Immune response to Cryptosporidium muris and Cryptosporidium parvum in adult immunocompetent or immunocompromised (nude and SCID) mice. Infect. Immun. 60, 33253331.

McDonald, V., Bancroft, G.J., 1994. Mechanisms of innate and acquired resistance to Cryptosporidium parvum infection in SCID mice. Parasite Immunol. 16, 315-320.

Pasquali, P., Fayer, R., Almeria, S., Trout, J., Polidori, G.A., Gasbarre, L.C., 1997. Lymphocyte dynamic patterns in cattle during a primary infection with Cryptosporidium parvum. J. Parasitol. 83, 247-250.

Rehg, J.E., 1996. Effect of interferon-gamma in experimental Cryptosporidium parvum infection. J. Infect. Dis. 174, 229-232.

Riggs, M., 1997. Immunology: host response and development of passive immunotherapy and vaccines. In: Fayer, R. (Ed.), Cryptosporidium and Cryptosporidiosis. CRC Press, Boca Raton, FL, pp. 129-161.

Riggs, M., 2002. Recent advances in cryptosporidiosis: the immune response. Microbes Infect. 4, 1067-1080.

Romani, L., Puccetti, P., Bistoni, F., 1997. Interleukin-12 in infectious diseases. Clin. Microbiol. Rev. 10, 611-636.

Solano-Aguilar, G.I., Zarlenga, D., Beshah, E., Vengroski, K., Gasbarre, L., Junker, D., Cochran, M., Weston, C., Valencia, D., Chiang, C., Dawson, H., Urban, J.F., Lunney, J.K., 2002. Limited effect of recombinant porcine interleukin-12 on porcine lymphocytes due to a low level of IL-12 beta2 receptor. Vet. Immunol. Immunopathol. 89, 133-148.

Theodos, C.M., Sullivan, K.L., Griffiths, J.K., Tzipori, S., 1997. Profiles of healing and non healing Cryptosporidium parvum infection in C57BL/6 mice with functional B and T lymphocytes: the extent of gamma interferon modulation determines the outcome of infection. Infect. Immun. 65, 4761-4769.

Trinchieri, G., 1998. Proinfiammatory and immunoregulatory functions of interleukin-12. Int. Rev. Immunol. 16, 365-396.

Ungar, B.L.P., Kao, T., Burris, J.A., Finkelman, F.D., 1991. Cryptosporidium infection in an adult mouse model. Independent roles for IFN-gamma and CD4+ T lymphocytes in protective immunity. J. Immunol. 147, 1014-1022.

Urban, J.F., Fayer, R., Chen, S., Gause, W.C., Gately, M.K., Finkelman, F.D., 1996. Il-12 protects immunocompetent and immunodeficient neonatal mice against infection with Cryptosporidium parvum. J. Immunol. 156, 263-268. 
Wyatt, C.R., Brackett, E.J., Savidge, J., 2001. Evidence for the emergence of a type-1-like immune response in intestinal mucosa of calves recovering from cryptosporidiosis. J. Parasitol. 87, 90-95.

Zarlenga, D.S., Canals, A., Aschenbrenner, R.A., Gasbarre, L.C., 1995a. Enzymatic amplification and molecular cloning of cDNA encoding the small and large subunits of bovine interleukin-12 Biochim. Biophys. Acta 1270, 215-217.

Zarlenga, D.S., Canals, A., Gasbarre, L.C., 1995b. Method for constructing internal standards for use in competitive PCR. Biotechniques 19, 324-326. 